\title{
Bafa ve Azap göl yüzey alanlarındaki zamansal değişimin belirlenmesi*
}

\author{
Hilal TOPÇU KÖSEER ${ }^{\circledR}$ 1, Levent ATATANIR ${ }^{\circledR} 2$
}

\author{
${ }^{1}$ Tarım ve Orman Bakanlığı Kiraz İlçe Müdürlüğü, İzmir \\ ${ }^{2}$ Aydın Adnan Menderes Üniversitesi Ziraat Fakültesi Toprak Bilimi ve Bitki Besleme Bölümü, Aydın \\ *Bu çalışma Aydın Adnan Menderes Üniversitesi Fen Bilimleri Enstitüsü Toprak Bilimi ve Bitki Besleme Anabilim Dalı'nda kabul edilen
yüksek lisans tezinden üretilmiştir.
}

Alınış tarihi: 9 Eylül 2020, Kabul tarihi: 12 Kasım 2020

Sorumlu yazar: Levent ATATANIR, e-posta: latatanir@adu.edu.tr

\section{Öz}

Amaç: Dünyada artan nüfusun su ihtiyacını karşılayan en önemli kaynaklardan olan yüzey suları küresel iklim değişiminden de en fazla etkilenen alanların başında gelmektedir. Bu nedenle yüzey sularındaki değişimlerin tespit edilmesi ve izlenmesi sürdürülebilir su kaynakları yönetiminde en önemli göstergelerinden biri haline gelmiștir. Bu çalıșma ile Bafa ve Azap Gölleri su yüzeylerindeki değişimler uzaktan algilama ve coğrafi bilgi sistemlerinden faydalanılarak tespit edilmiştir.

Materyal ve Yöntem: Çalışmada 1987, 1999, 2007 ve 2015 ylllarma ait Landsat, 2014 tarihli Rapideye uydu görüntüleri, 2010 tarihli ortofoto görüntüler ile 1996 ve 2012 tarihinde üretilmiş topografik haritalar kullanılmıştır. Su yüzeylerinin alansal tespitinde manuel sayısallaştırma, kontrollü ve kontrolsüz sinıflandırma ile NDWI analizi kullanılmıştır.

Araştırma Bulguları: Dönemsel olarak yaşanan taşkınların özellikle Azap göl alanında önemli değişimlere sebep olduğu, kurak dönemde ise hızlı bir daralma gösterdiği belirlenmiştir. Yüksek yersel çözünürlüğün hem sayısallaştırmada hem de sınıflandırmada başarı oranını arttırdığı tespit edilmiștir. Farklı derinlikteki su yüzeylerine sahip alanlarda kontrolsüz sınıflamanın başarılı sonuçlar verdiği, kontrollü sinıflamada ise hataların artabileceği değerlendirilmiştir. İlgi alanı kullanarak oluşturulan vektör veriler ve NDWI yönteminin su yüzeylerinin tespit edilmesinde kullanılabileceği test edilerek ortaya konulmuştur.
Sonuç: Azap gölü su yüzeylerinde 1987 ile 2007 yılları arasında yaklaşık \%90 daralma meydana geldiği, 2014 yılına gelindiğinde yaklaşık 9 kat genişlediği, son bir yılda ise tekrar daralmaya girdiği belirlenmiştir. Bafa gölünde farklı yıllarda su yüzeylerindeki artış ve azalışların birbirini takip ettiği ortaya çıkmıştır.

Anahtar Kelimeler: Bafa Gölü, Azap Gölü, Zamansal Değişim, Uzaktan Algılama

\section{Determination of temporal changes in Bafa and Azap Lake Surface Areas}

\begin{abstract}
Objective: Surface waters, primary source of water for growing population in the World, are highly affected by global climate change. Therefore, detecting and monitoring changes in surface waters has become one of the most important indicators in sustainable water resources management. In this study, the changes in water surfaces of Bafa and Azap Lakes were determined by using remote sensing and geographical information systems.
\end{abstract}

Material and Methods: In the study, Landsat images taken in 1987, 1999, 2007 and 2015, Rapideye satellite images taken in 2014, orthophoto images taken in 2010 and topographic maps produced in 1996 and 2012 were used. Manual digitization, supervised and unsupervised classification and NDWI analysis were used for spatial determination of water surfaces. 
Results: It has been determined that periodic floods caused significant changes especially in the Azap lake area, and it shrinked rapidly in dry periods. It was found that high spatial resolution increased the success rate of digitization and classification. It has been evaluated that unsupervised classification yields successful results in areas with different depths of water surface, while errors may increase in supervised classification. It has been demonstrated that the vector data generated using the area of interest and the NDWI method can be used to detect water surfaces.

Conclusion: It has been determined that the water surfaces of Lake Azap contracted approximately 90\% between 1987 and 2007, expanded approximately 9 times in 2014, and contracted again in the last year. In Lake Bafa, it has been revealed that the increases and decreases in water surfaces in different years follow each other.

Key words: Bafa Lake, Azap Lake, Temporal Change, Remote Sensing

\section{Giriş}

İnsanların yerleşik düzene geçmesi, çevrelerinde yer alan doğal kaynaklar üzerine baskılarını gündeme getirmiştir. Özellikle de hayatın devamlılı̆̆ için elzem olan su yüzeyleri farklı amaçlar için yoğun şekilde kullanılmış ve hala da bu kullanım devam etmektedir. Sürdürülebilirlik açısından bu alanların izlenmesi ve gerekli durumlarda koruma altına alınması gereklilik haline gelmiştir.

Türkiye Ramsar Sözleşmesine 1993 yllında imza atmıștır. Ocak 2004 itibariyle sözleşmeye 134 ülke taraf olmuștur. Bu ülkeler toplam alanı 111.884.289 hektar olan 1.328 sulak alanı sözleşme çizelgesine dahil ettirmişlerdir (Erdem, 2004; Karakılçık ve Özcan, 2009). Sulak alanlar; doğal dengenin ve biyolojik çeşitliliğin korunması yönünden diğer ekosistemler içinde önemli ve farklı bir yere sahiptirler (Soydan, 2013). Türkiye'de Ramsar Sözleşmesi kapsamında 2013 yılı itibariyle Bitlis'deki Nemrut Kalderası ile toplam 14 alan listeye eklenmiştir. Çalıșma alanına konu olan Bafa ve Azap sulak alanları bu sözleşmeye dâhil edilmemiştir. Bafa Gölü, 08.07.1994 tarihinde Tabiat Parkı ilan edilmeden önce 1989 yılında sit alanı ilan edilmiştir. Azap Gölü ise Büyük Menderes Deltası ve Bafa Gölü'nden sonra Aydın'ın üçüncü büyük sulak alanıdır (Tunçay ve ark., 2009). Buna rağmen Azap Gölü koruma altına alınmamış ve Aydın Doğa
Koruma ve Milli Parklar Şubesince 2006 yılı Sulak Alan envanter çalışması kapsamına alınmıştır.

Küresel ısınmanın etkileri düşünüldüğünde su yüzeylerinin önemi bir kat daha artmaktadır. Geçmişten ders alınması gerçeği, bu iki gölün yanlış uygulamalar sonucu yok olma noktasına gelmiş olan Aral gölü benzeri bir durum yaşanmasını engelleyecektir. Bafa ve Azap göllerinin Ramsar sözleşmesi kapsamına alınması ise önlemlerin yasalar düzeyinde çok daha uygulanabilir olmasını sağlayacaktır.

Yüzey suları içerisinde önemli bir yere sahip olan göllerin zaman içerisindeki değişimlerini tespit etmek amacıyla hava fotoğraflarının (Papastergiadou ve ark., 2008), yer ve uydu verilerinin (Ekercin ve Örmeci, 2008), uydu görüntüleri üzerinden kontrollü ve kontrolsüz sınıflandırma yanında indekslerin (Karabulut, 2015; Hossen ve Negm, 2016; Aksoy ve ark., 2019) ve çeşitli algoritmaların (Ma ve ark., 2014; Erener ve Yakar, 2015) kullanıldığı bir çok çalışma bulunmaktadır. Uzaktan algılama teknolojisi; bilgiye çok kısa sürede, güvenilir ve ekonomik bir şekilde ulaşmayı sağlamaktadır. Elde edilen sonuçlar değerlendirilerek yapılacak çalışmalar ve alınacak önlemler kısa sürede planlanabilmektedir (Tunay ve Ateşoğlu, 2004). Bu çalışma ile Bafa ve Azap Gölleri su yüzeylerinde zaman içerisinde meydana gelen değişimler uzaktan algılamanın farklı yöntemleri ve coğrafi bilgi sistemlerinden faydalanılarak tespit edilmiştir.

\section{Materyal ve yöntem}

Çalışmada temel kartografik materyal olarak; 1987 (5TM), 1999, 2007 (ETM) ve 2015 (80LI) tarihli Landsat, 2014 tarihli Rapideye uydu görüntüleri, 2010 tarihli ortofoto görüntüler ve 1/25.000 ölçekli standart topografik haritalardan faydalanılmıștır. Raster formattaki uydu görüntülerinin işlenmesi ve değerlendirmelerinin yapılması aşamasında ERDAS Imagine Professional 8.7, vektörel formattaki verilerle ilgili çalışmalar aşamasında ise ArcGIS 9.3 yazılımlarından yararlanılmıştır.

\section{Çalışma Alanına Ait Bilgiler}

Çalışma alanı; Muğla İli Milas, Aydın İli Söke ve Didim ilçe sınırları içerisinde $37^{\circ} 26^{\prime} 32^{\prime \prime}-37^{\circ} 37^{\prime} 15^{\prime \prime}$

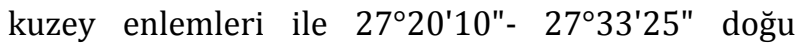
boylamları arasında yer almakta olup, 27.850 ha alan kaplamakta ve deniz seviyesinden 5 ile $700 \mathrm{~m}$ ye kadar olan yüksekliklere sahip bulunmaktadır (Şekil 1). 


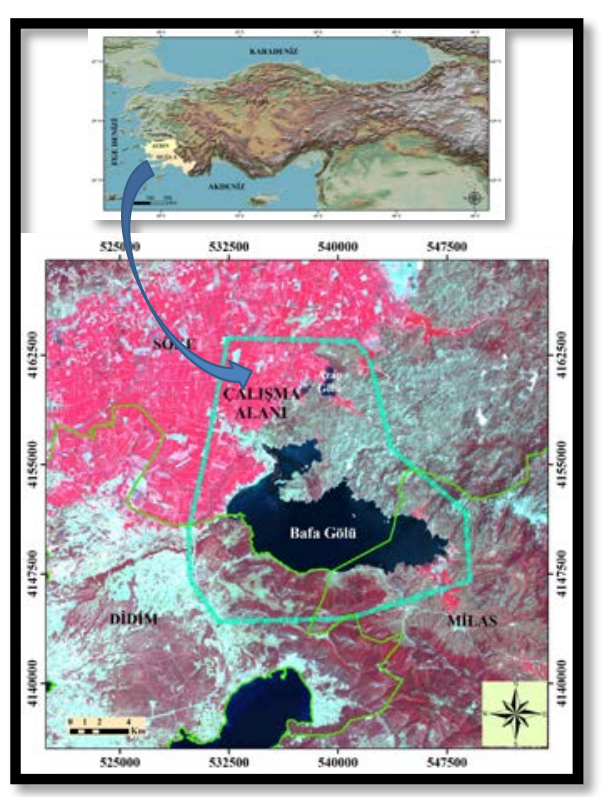

Şekil 1. Çalıșma Alanının Coğrafi Konumu

Çalışma alanı iklim özellikleri bakımından Akdeniz iklim tipine girmektedir. Göl çevreleri saz, sögüt, ılgın, zeytin, maki ve çam ormanları ile kaplıdır. Göllerin yakınındaki tarım alanlarında pamuk ve mısır yetiştiriciliği yapılmaktadır. Göller, bünyesinde çok sayıda kuş ve balık türünü barındırmaktadır. Bafa ve Azap Göllerini de içerisinde bulunduran Menderes Masifi, Alpin Orojenik Kuşak içerisinde geniș alanda yüzeylenen metamorfik bir komplekstir (Koralay ve ark., 2011). Türkiye'nin en büyük kıyısal göllerinden biri olan Bafa, Büyük Menderes Nehri tarafından getirilen alüvyonlarla Latimian (Latmos) Körfezi olarak isimlendirilen koyun neredeyse tamamını doldurması sonucu oluşmuş bir set gölüdür. Menderes nehrinin aktivitesi sonucu MS 300 yıllarında açık denizle bağlantısı tamamen kopan Azap Gölü'nün ardından MS 1500'lü yıllarda ise Bafa Gölü benzer bir durum yaşamıştır (Müllenhoff ve ark., 2004; Hepsögüttü, 2012). Her iki gölde günümüzde Menderes nehrinin taşkınları sonucunda gelen sular yanında yerüstü ve yeraltı su kaynakları tarafından beslenmektedirler. Gölleri çevreleyen yüksek arazilerdeki materyallerin ayrışması, taşınması ve biriktirilmesi sonucu oluşan kolüviyal araziler alanda görülmekle birlikte genelde ana materyalin özelliğini taşıyan yerinde oluşumun hakim olduğu görülmektedir. Gözlü gnayslar ve mermer formasyonları geniş alanlarda yüzlek vermektedir. Benzer şekilde gölleri besleyen derelerin göl haznesine ulaştığı alanlarda getirip yığmış olduğu sedimentleri biriktirmesi sonucu olușan alüviyal alanlarda mevcuttur.

\section{Yöntem}

Farklı yllarda üretilmiş olan topografik haritalar üzerinden ArcGIS programı yardımıyla göl alanlarına ait veriler bilgisayar ekranı üzerinden manuel olarak sayısallaştırılarak vektörel formata dönüştürülmüşlerdir.

Raster formattaki uydu görüntüleri, çalışma alanına ait sınırlar kullanılarak oluşturulmuş olan ilgi alanı (AOI) dikkate alınarak Erdas 8.7 programıla kesilmiştir. Elde edilen görüntülerde histogram değerlerinin azalması sonucu görüntülerin yorumlanması ve uygulanacak olan işlemlerin hızı ve doğruluğu arttırılmıştır. Mevcut uydu görüntüleri üzerinden göl haznelerinde olan zamansal değişimin tespiti için manuel sayısallaştırma ve ilgi alanından vektörel forma dönüşüm, unsupervised (kontrolsüz), supervised (kontrollü) ve Normalize Edilmiş Fark Su İndeksi (NDWI) yöntemleri denenmiştir.

Önceki çalışmalardan elde edilmiş olan bilgiler ışığında taşkınların sıklıkla yaşandığı Mart ayında ön arazi ve suların çekilmesinden sonra tarımsal uygulamalara geçilmiş olan Eylül ayında olmak üzere iki dönem arazi çıkışı gerçekleștirilmiştir (Şekil 2).

\section{Bulgular}

1996 ve 2012 yıllarında Harita Genel Komutanlığı tarafından basılmış topografik haritalar üzerinden manuel olarak yapılan sayısallaştırmalar sayesinde Azap ve Bafa göllerinde meydana gelmiş olan değişimler vektörel ve alansal olarak ortaya çıkarılmıştır. Sayısallaştırmada sadece su yüzeylerinin varlığı dikkate alınmış, sazlık ve kumul alanlar değerlendirmeye alınmamıştır (Şekil 3). Göl alanlarında meydana gelen değişim alansal olarak değerlendirildiğinde Bafa Gölünde 1.033 ha'lık (\% 18.25) Azap Gölü'nde ise 89 ha'llk (\% 593.3) bir büyüme olduğu tespit edilmiştir (Çizelge 1).

Kullanılan uydu görüntülerinin seçiminde yaklaşı k benzer aylara ait görüntüler tercih edilmiştir. 05/06/1987 tarihli Landsat5 TM, 01/08/1999 ve 15/08/2007 tarihli Landsat7 ETM, 20/07/2015 tarihli Landsat8 OLI ve 14/07/2014 tarihli Rapideye görüntüleri bu amaçla kullanılmıştır. Taşkın zararının tespitinde ise arazi çıkışı ile örtüşecek 20/04/2015 tarihli Landsat8 OLI görüntüsünden faydalanılmıştır. Materyal olarak kullanılan uydu ve ortofoto görüntüler karşılaştırıldığında; ortofoto görüntülerin $0.45 \mathrm{~m}$, Rapideye uydu görüntüsünün 5 $\mathrm{m}$ ve Landsat uydu görüntülerinin ise $30 \mathrm{~m}$ yersel çözünürlüğe sahip oldukları görülmektedir (Şekil 4). 

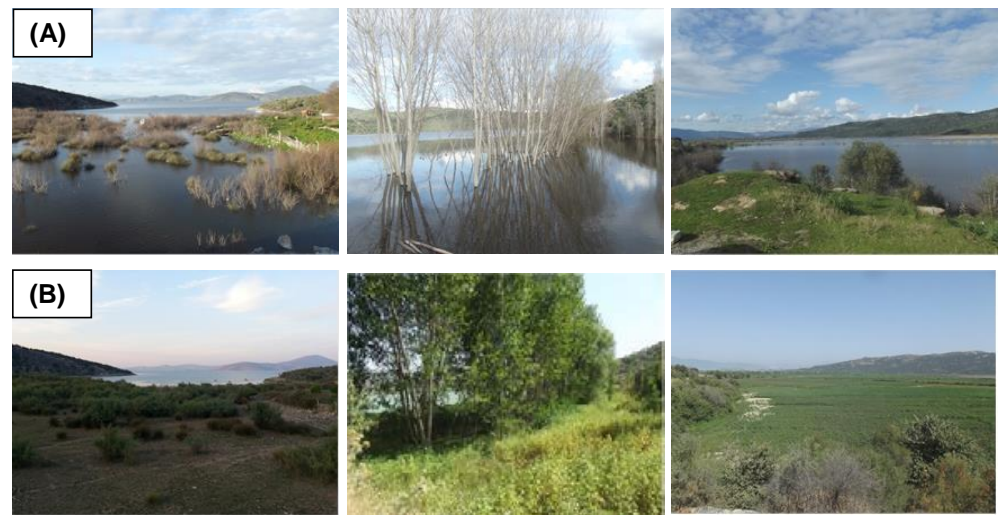

Şekil 2. Mart (A) ve Eylül (B) aylarına ait görünümler

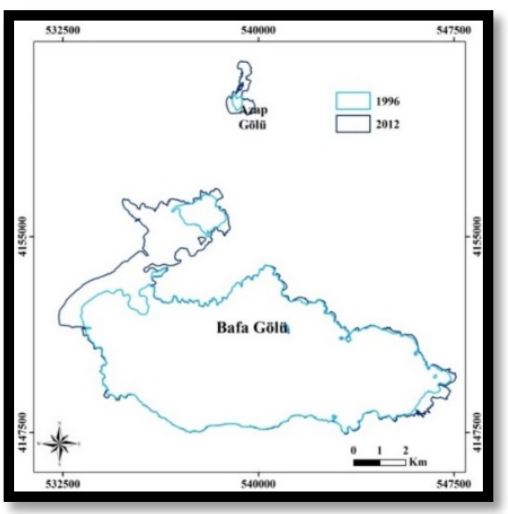

Şekil 3. Göl Alanlarının Zaman İçindeki Değişimi

Çizelge 1. Alan Olarak Göllerdeki Değiş̧im

\begin{tabular}{lcccc}
\hline & $\begin{array}{c}1996 \\
\text { (ha) }\end{array}$ & $\begin{array}{c}2012 \\
\text { (ha) }\end{array}$ & $\begin{array}{c}\text { Fark } \\
\text { (ha) }\end{array}$ & $\begin{array}{c}\text { Büyüme } \\
(\%)\end{array}$ \\
\hline Bafa Gölü & 5658 & 6691 & 1033 & 18.25 \\
Azap Gölü & 15 & 104 & 89 & 593.3 \\
\hline
\end{tabular}
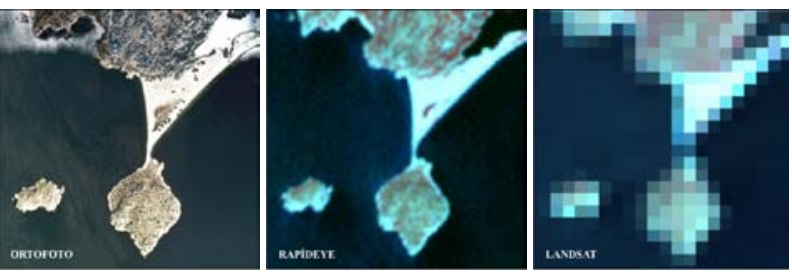

Şekil 4. Kullanılan Materyallerin Yersel Çözünürlükleri

Ortofoto görüntüler özellikle alansal çalışmalarda manuel olarak gerçekleștirilecek sayısallaștırmalar için büyük avantajlar sağlamaktadır. Belli aralıklarla temin edilebilecek görüntüler ile sayısal verideki değişimler rahatlıkla izlenebilmektedir. Kıyı kesiminde meydana gelen değişimlerin $\mathrm{cm}$ düzeyinde belirlenebilmesi, toplam su yüzeyindeki azalmanın veya artışında hesaplanabilmesini sağlayacaktır. Günümüzde görsel yanında yakın infrared bandı da beraberinde içeren görüntülerin temini mümkündür. Ancak maliyetli olmaları kullanıcıları alternatif ürünlere yönlendirmektedir. Yüksek yersel çözünürlüğe sahip uydular bu amaçla yaygın şekilde kullanılır hale gelmiştir. Mevcut ortofoto görüntüler üzerinden gerçekleştirilen sayısallaştırma işlemi ile 2010 yılında göllerin su ile kaplı alanları belirlenmiştir. Alansal değerlendirme yapıldığında Azap Gölü'nün 100.3 ha, Bafa Gölünün ise 6730.0 ha alan kapladığı tespit edilmiştir (Şekil 5). 2012 tarihli topografik harita üzerinden yapılan sayısallaştırma sonuçları ile karşılaştırıldığında Azap Gölünde 3.7 ha'lık (\%3.7), Bafa Gölü'nde ise 39 ha'llk (\%0.6) bir farklılık tespit edilmiştir. Benzer şekilde Rapideye uydu görüntüsü içinde ekran üzerinden sayısallaştırma gerçekleştirilmiştir. Ancak piksel boyutlarının ortofoto görüntülere göre 10 kattan fazla olması sayısallaştırma işleminin doğruluğunu azaltmaktadır. Elde edilen sonuçlar 2014 yllında Azap Gölü'nün 98.2 ha, Bafa Gölü'nün ise 6739.8 ha alana sahip olduğunu göstermektedir (Şekil 5). Üretilen veri daha sonra farklı yöntemlerle belirlenecek olan göl alanları ile karşılaştırmasının yapılması açısından önem taşımaktadır.
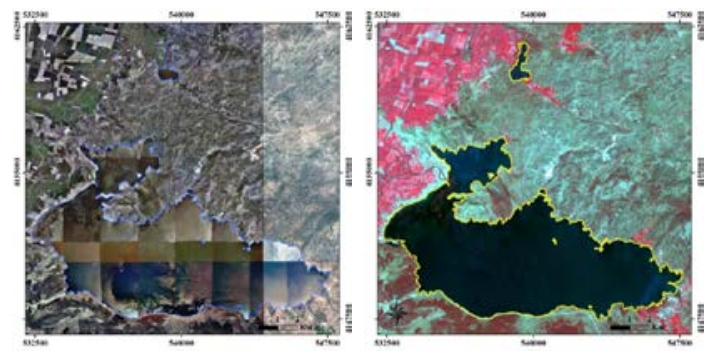

Şekil 5. Manuel Olarak Sayısallaştırılmış Göl Alanları

Çalışma kapsamında su yüzeylerinin belirlenebilirliğinin yüksek olmasından dolayı uydu görüntülerindeki mevcut piksel değerlerini kullanarak benzer unsurları ortaya çıkarmayı hedefleyen kontrolsüz sinıflama yöntemleri 
kullanılarak göl alanlarındaki zamansal değişimler tespit edilmiştir. $\mathrm{Bu}$ amaçla ilk olarak arazi çıkışlarının da gerçekleştirildiği 2015 yılının Nisan ve Temmuz aylarına ait Landsat uydu görüntülerinde 4 sınıf olacak şekilde kontrolsüz sınıflandırma işlemi gerçekleştirilmiş ve alansal olarak taşkın sonrası alanlardaki değişim tespit edilmeye çalışılmıştır (Şekil 6).
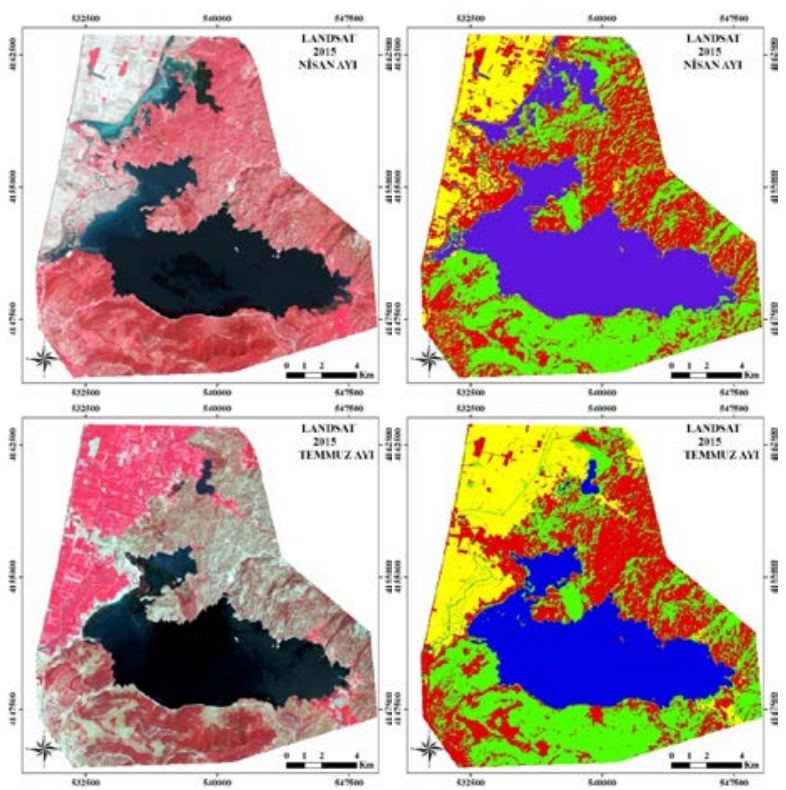

Șekil 6. Uydu ve Sınıflandırılmıș Görüntülerde Tașkının Etkisi

Görüntülerin görsel yorumlamasıyla bile Nisan ayında meydana gelen taşkının göl haznelerinde yaratmış olduğu değişimler kolaylıkla belirlenebilmektedir. Elde edilen sonuçlar değerlendirildiğinde Nisan ayında Menderes Nehri ile birleşen Azap Gölünün alanının 960.5 ha olduğu Temmuz ayına gelindiğinde ise 92.2 ha alan kapladığı tespit edilmiştir. Bu durumda göl hacmi Temmuz ayına göre 10 kat artıș göstermiștir. Bafa Gölündeki durum incelendiğinde ise Nisan ayında 7064.4 ha olan alanın Temmuz ayında 457.2 ha (\% 6.5) azalarak 6607.2 ha'a indiği belirlenmiştir. Sonuçlar Bafa Gölünün tașkından çok düșük sevilerde etkilendiğini ortaya koymaktadır. Aynı yöntem kullanılarak farklı tarihlerdeki uydu görüntüleri de kontrolsüz olarak sınıflandırılmıștır (Şekil 7).

Sınıflandırılmış uydu görüntülerinde göl alanlarının değerlendirmesi ayrı ayrı yapılmıştır (Çizelge 2). Azap Gölünde 1987 yılından 2007 yılına kadar önemli azalmalar tespit edilmiş olup, 2007 yllındaki kurak dönemde gölün tamamen kuruduğuna dair birçok yerel gazetede haberler yer almaktadır. Daha sonraki yıllarda göl alanında tekrar bir artış meydana gelmiştir. Bafa Gölü 1987 yılında en küçük alana sahipken, 2007'deki kurak dönemden de etkilenmiş olduğu ve diğer ylllarda çok büyük değişimlerin meydana gelmediği belirlenmiștir.

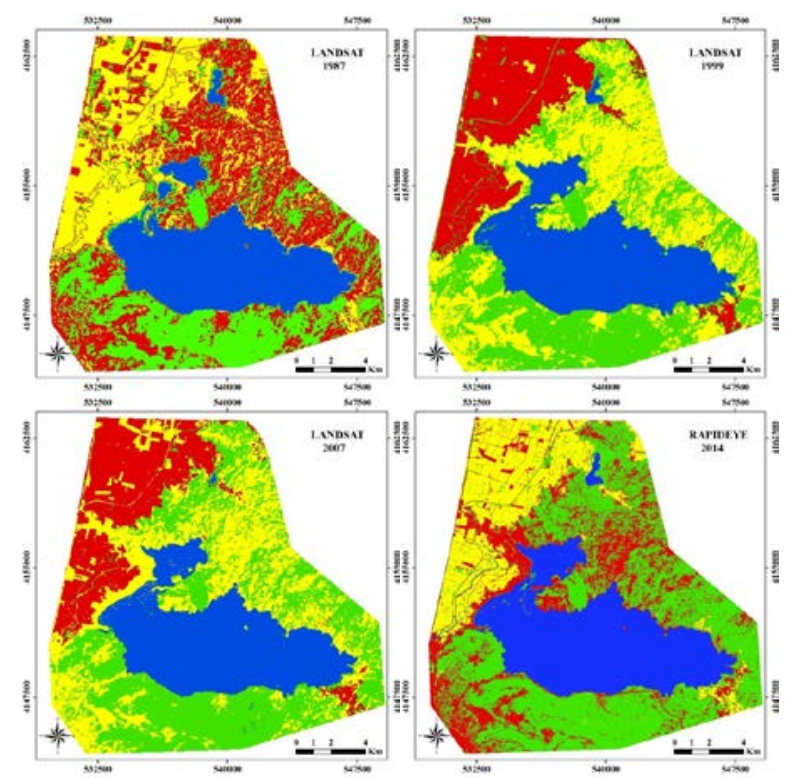

Șekil 7. Kontrolsüz Sınıflanmıș Uydu Görüntüleri

Çizelge 2. Kontrolsüz Sinıflama Sonucu Göl Alanı Değişimleri

\begin{tabular}{cccccc}
\hline & $\begin{array}{c}1987 \\
\text { (ha) }\end{array}$ & $\begin{array}{c}1999 \\
\text { (ha) }\end{array}$ & $\begin{array}{c}2007 \\
\text { (ha) }\end{array}$ & $\begin{array}{c}2014 \\
\text { (ha) }\end{array}$ & $\begin{array}{c}2015 \\
\text { (ha) }\end{array}$ \\
\hline Bafa Gölü & 5906.8 & 6636.2 & 6407.7 & 6657.4 & 6607.2 \\
Azap Gölü & 119.3 & 82.2 & 16.5 & 96.4 & 92.2 \\
\hline
\end{tabular}

2014 yılına ait Rapideye uydu görüntüsünün manuel sayısallaştırması ile sınıflandırmadan elde edilmiş olan değerleri karşılaştırıldığında, Azap Gölü'nün 1.8 ha (\% 1.8), Bafa Gölünün ise 82.4 ha (\% 1.2) daha büyük belirlenmiş olduğu ortaya çıkmaktadır. Yüzdeler bazında hata payı değerlendirildiğinde farklılıkların çok önemli boyutlarda olmadığı görülmektedir.

Erdas programı içerisinde yer alan Region Growing Properties özelliğinden yararlanılarak göl alanları için bilgisayar tarafından çizilen ilgi alanları vektör formata dönüștürülerek doğrulukları belirlenmeye çalışılmıştır. Üretilen ilgi alanlarında sayısallaştırma sırasında gözden kaçan ve göl içerisinde suların çekilmesiyle ortaya çıkmış olan alanların bile bilgisayar tarafından algılandığı ve çizimlerin daha gerçekçi olarak ortaya çıktıkları tespit edilmiştir. $\mathrm{Bu}$ durumda yersel çözünürlükleri yüksek olmayan uydu görüntülerinin manuel sayısallaştırma yerine 
bu yöntemle vektör formata dönüștürülmelerinin daha faydalı olacağı kanısına varılmıștır. Daha önce hem manuel sayısallaştırma hem de sınıflandırma ile elde edilmiş verilere sahip olmasından dolayı Rapideye uydu görüntüsü için yapılan işlem sonucu ortaya çıkan göl alanları değerlendirmede Azap Gölü'nün 99.2 ha, Bafa Gölünün ise 6.595 ha olarak hızlı bir şekilde hesaplandığı tespit edilmiştir (Şekil 8). Manuel sayısallaştırma sonuçları ile karşılaştırıldığında Bafa gölünde \%2.2, Azap gölünde ise \%1, kontrolsüz sinıflandırma sonuçları ile ise sırasıyla \%0.94 ve \%2.8'lik bir farklılık olduğu belirlenmiștir. Zamanı ekonomik kullanmak adına programların sağlamış olduğu kısa yolların oldukça faydalı oldukları görülmektedir.

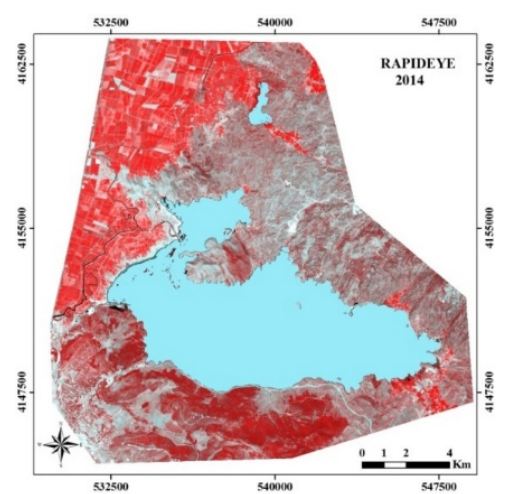

Şekil 8. Otomatik Olarak Çizdirilmiş Göl Alanları

Çalışma kapsamında uydu görüntüleri kontrollü sınıflandırma işlemine tabi tutulmuşlardır (Şekil 9). Sınıflandırma sonucu elde edilmiş olan görüntülerde göl alanlarının diğer su yüzeyleri ile olan karıșmasını önlemek adına ayrı ayrı kesilerek alansal değişimleri belirlenmiştir (Çizelge 3). Elde edilen sonuçlar kontrolsüz sınıflandırmalar ile karşılaştırıldığında, yıllar içerisinde su yüzeylerindeki artış ve azalış miktarlarının birbirine paralellik gösterdiği görülmektedir. Kontrollü sinıflandırmada sığ su yüzeyi ve askıda materyal içeren alanların farklı sınıflar içerisinde yer aldıkları bu sebeple alansal hesaplamalarda daralmalar meydana geldiği tespit edilmiştir.

Çizelge 3. Kontrollü Sinıflama Sonucu Göl Alanı Değişimleri

\begin{tabular}{cccccc}
\hline & $\begin{array}{c}1987 \\
\text { (ha) }\end{array}$ & $\begin{array}{c}1999 \\
\text { (ha) }\end{array}$ & $\begin{array}{c}2007 \\
\text { (ha) }\end{array}$ & $\begin{array}{c}2014 \\
\text { (ha) }\end{array}$ & $\begin{array}{c}2015 \\
\text { (ha) }\end{array}$ \\
\hline Bafa Gölü & 5676.8 & 6399.7 & 6145.4 & 6454.0 & 6024.0 \\
Azap Gölü & 84.8 & 59.1 & 9.3 & 88.0 & 75.8 \\
\hline
\end{tabular}

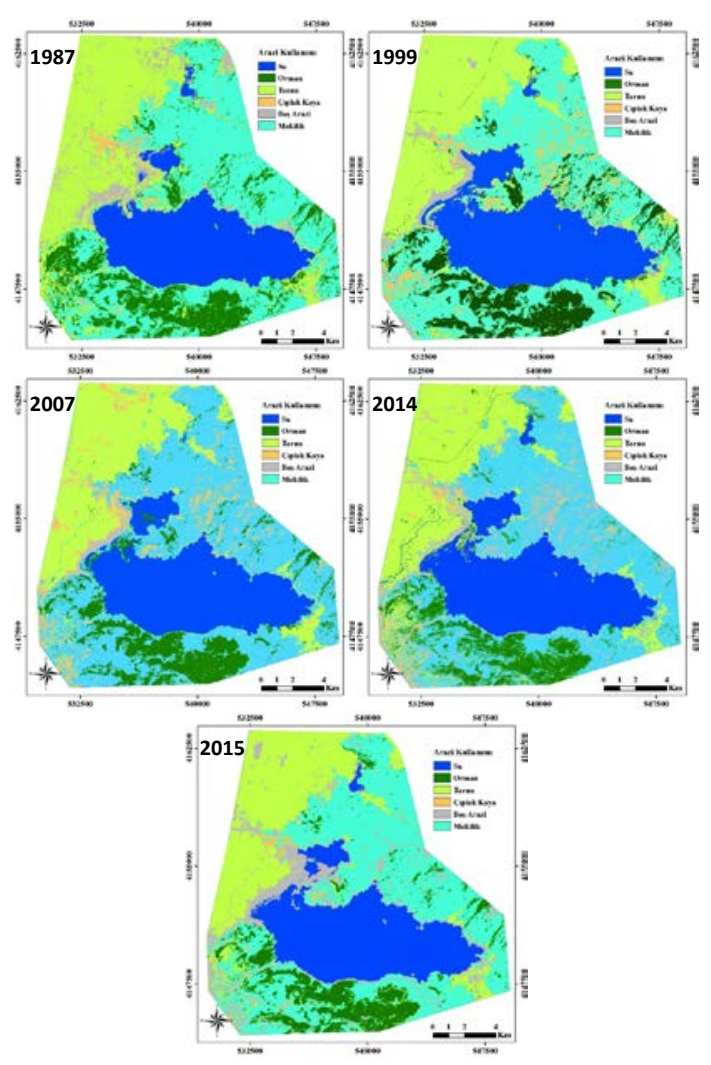

Şekil 9. Uyduların Kontrollü Sınıflandırma Sonuçları

Göl alanlarında gerçekleşen değişimleri tespit etmek amacıyla son olarak, Erdas yazılımının indeksler alanı içerisinde yer alan NDWI yöntemi kullanılmıştır. Göllerin çevresinde yer alan arazilerden karışımları engellemek amacıyla kontrollü sinıflamada olduğu gibi oluşturulan ilgi alanları dahilinde görüntüler kesilmiştir. Yöntemde yeşil ve yakın infrared bantlar esas alınmakta ve bandlar arasındaki farkın toplamlarına bölünmesi ile elde edilen sonuçlar -1 ila 1 arasında değişim göstermektedir. Genelde 0.1 veya 0.2 değerinden yüksek çlkan değerler su yüzeylerini tespit etmek için kullanılmıştır. Sonuçta elde edilen görüntüler Şekil $10 \mathrm{da}$, alansal değişimler ise Çizelge $4 \mathrm{de}$ verilmiştir. Yıllar içerisinde meydana gelen değişimlerin diğer sinıflandırma yöntemlerinde olduğu gibi küçük farklılıklarla tespit edilebildiği belirlenmiştir.

Çizelge 4. NDWI Sonucu Göl Alanı Değişimleri

\begin{tabular}{lccccc}
\hline & $\begin{array}{c}1987 \\
\text { (ha) }\end{array}$ & $\begin{array}{c}1999 \\
\text { (ha) }\end{array}$ & $\begin{array}{c}2007 \\
\text { (ha) }\end{array}$ & $\begin{array}{c}2014 \\
\text { (ha) }\end{array}$ & $\begin{array}{c}2015 \\
\text { (ha) }\end{array}$ \\
\hline Bafa NDWI & 5866 & 6441 & 6142 & 6349 & 6284 \\
Azap NDWI & 104.5 & 73.5 & 10.1 & 92.2 & 91.5 \\
\hline
\end{tabular}




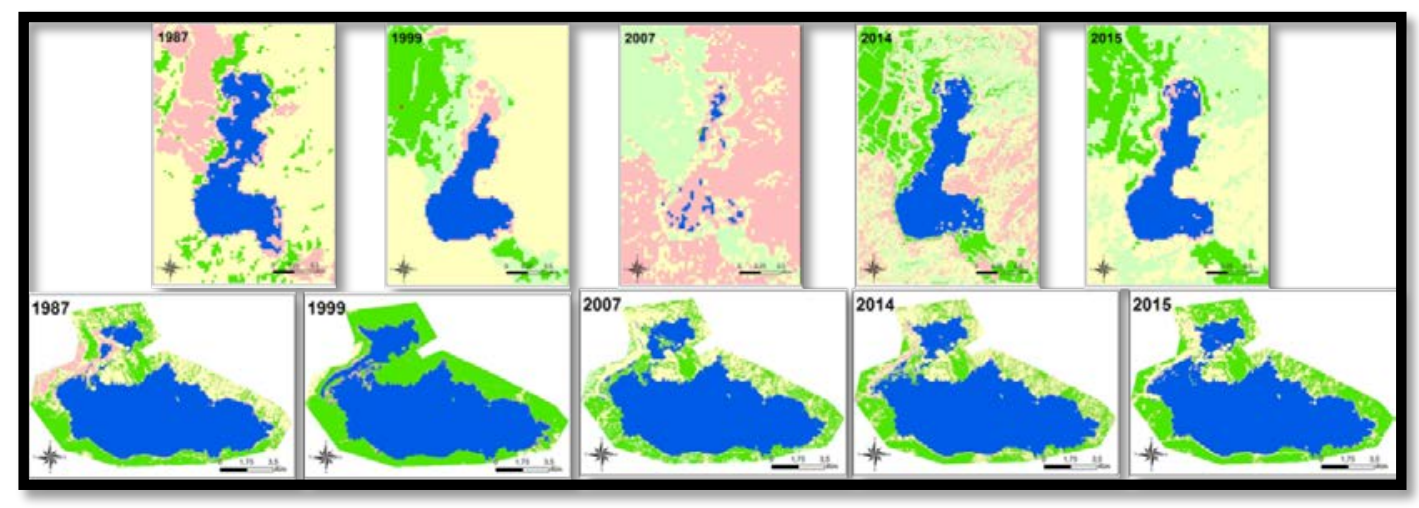

Şekil 10. NDWI yöntemi ile elde edilmiş göl alanları

Azap Gölü

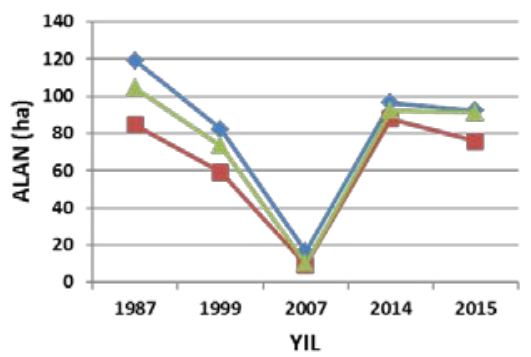

Bafa Gölü

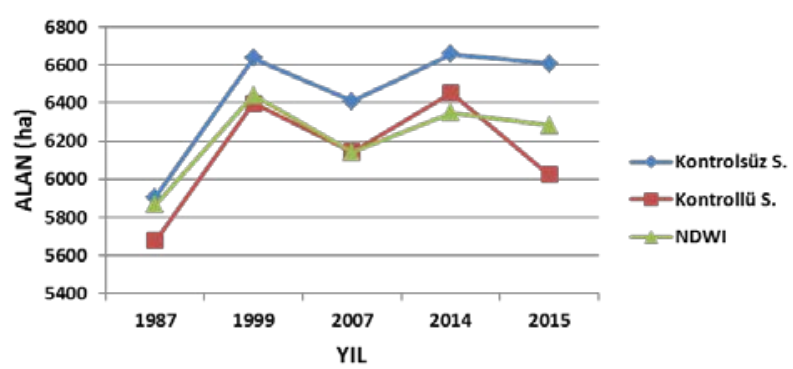

Şekil 11. Farklı yöntemlerle belirlenmiş göl alanlarındaki zamansal değişim

Göl alanlarının belirlenmesinde kullanılmıș olan yöntemler kendi aralarında görsel olarak kıyaslandığında, yıllar arasında meydana gelen değişimlerin belirlemesinde kullanılabilecekleri ortaya çıkmaktadır (Şekil 11).

\section{Sonuçlar ve Tartışma}

Günümüzde hızla artan su ihtiyacının temininde göl yüzeylerinin etkinliği oldukça önem taşımaktadır. Göllerdeki su seviyelerinin ve kalitelerinin izlenmesi aşamasında uzaktan algılama ve coğrafi bilgi sistemleri hızlı ve ekonomik sonuçlarla çalışmalara yön vermektedir. Uzaktan algılama ve CBS entegrasyonu ile mekândaki değişim, sürdürülebilirlik ve değişim eğilimlerinin tespit edilmesi sağlanabilmektedir. Yürütülen çalışma kapsaminda bu veri entegrasyonundan faydalanılarak gelecekte yürütülecek çalışmalar için bir veri tabanı meydana getirilmiştir.

Her yıl yaşanan Büyük Menderes Nehri'nin taşkınları sonucunda başta Azap Gölü olmak üzere göl alanlarında önemli değişimler meydana geldiği ve tarımsal üretim yapılan alanlarda önemli gecikmelerin ortaya çıktığı tespit edilmiştir. Taşkın kontrolü amaçlı muhafaza önlemlerinin bir an önce hayata geçirilmesi ve göllerin Ramsar sözleşmesi kapsamında koruma altına alınması gerekmektedir.

Göllerin su ile kaplı yüzeylerinin yıllar içerisindeki değişiminin tespit edilmesinde ilk olarak farklı yıllarda üretilmiş olan topografik haritaların manuel olarak sayısallaştırılmaları ve karşılaştırmaları gerçekleștirilmiştir. Sonuçlar özellikle Azap Gölünde yaklaşık altı kat, Bafa Gölünde ise 1/5 oranında bir artış olduğunu göstermiştir. Daha sonra 2012 yılına ait topografik haritadan üretilen vektör katman, aynı tarihli ortofoto görüntülerin bilgisayar ekranı üzerinden yapılan sayısallaştırmaları ile karşılaştırılmış ve yüksek oranda benzerlik içerdikleri tespit edilmiştir. Yüksek yersel çözünürlük, çalışmalarda başarı oranını arttırmaktadır. Benzer sonuçlar Rapideye uydu görüntüsünden yapılan sayısallaştırma ve kontrolsüz sınıflandırma sonuçlarında da elde edilmiştir. Sayısallaştırma için harcanan zaman kaybını azaltmak adına, programların sunmuş olduğu otomatik sayısallaştırma özelliklerinin yüksek oranda başarıya sahip oldukları belirlenmiştir.

Sinıflandırmalar arasında kontrolsüz sınıflama ile elde edilen değerlerin diğer yöntemlere göre su yüzeylerinin belirlenmesinde çok hızlı bir teknik 
olduğu, ancak elde edilen alansal verilerin daha yüksek değerler içerdiği tespit edilmiştir. Kontrollü sınıflandırmada ise çok sığ su yüzeylerinde yüzey altı materyalden veya biyolojik oksijen noksanlığ sonucu ortaya çıkan mavi-yeşil alg popülasyonundan dolayı sinıflandırmada alansal kayıplara neden olabilmektedir. Bu sebeple NDWI yöntemi ile tespit edilen alanların değişim tespitinde kullanılması daha faydalı olacaktır.

\section{Çıkar çatışması}

Yazarlar arasında herhangi bir çıkar çatışması yoktur.

\section{Yazarların katkı beyanı}

HTK: Yüksek Lisans Tezi kapsamında araștırmanın tamamında katkıda bulunmuştur. LA: Araştırmanın yürütülmesi ve yayın haline getirilmesinde katkı sağlamıştır.

\section{Teşekkür}

$\mathrm{Bu}$ çalışma Aydın Adnan Menderes Üniversitesi BAP birimi tarafindan desteklenen ZRF-15008 nolu proje kapsamında gerçekleştirilmiştir.

\section{Kaynaklar}

Aksoy, T., Sarı, S., \& Çabuk, A. (2019). Sulak Alanların Yönetimi Kapsamında Su İndeksinin Uzaktan Algılama ile Tespiti, Göller Yöresi. GSI Journals Serie B: Advancements in Business and Economics, 1: $35-48$

Ekercin, S., \& Örmeci, C. (2008). Tuz Gölü'ndeki su rezervi değișiminin çok zamanlı LANDSAT uydu görüntüleri ve eş-zamanlı yersel ölçmeler ile analizi. İTÜ Dergisi, 7: 29-40.

Erdem, O. (2004, 28 Șubat). Sulak Alanlar: Önemi, Temel Sorunları, Türkiye'nin Uluslararası Öneme Sahip Sulak Alanları. Haber Ekspres Gazetesi, İzmir.

Erener, A., \& Yakar, M. (2015). Uzaktan Algllama ve CBS Teknolojileri ile Kıyı Sınır Değișim Analizi: Meke Gölü Örneği. TUFUAB VIII. Teknik Sempozyumu, Konya, 1:193-197.

Hepsögütlü, D. (2012). Bafa Gölü'nün Makrobentik Organizmaları ve Bazı Fizikokimyasal Değișkenleri. Dokuz Eylül Üniversitesi Fen Bilimleri Enstitüsü, Yüksek Lisans Tezi, İzmir.

Hossen, H., \& Negm, A. (2016). Change Detection of Manzala Lake Using Remote Sensing and Geographic Information System. The Egyptian
International Journal of Engineering Sciences and Technology, 19: 353-358.

Karabulut, M. (2015). Farklı Uzaktan Algılama Teknikleri Kullanılarak Göksu Deltası Göllerinde Zamansal Değişimlerin İncelenmesi. Uluslararası Sosyal Araştırmalar Dergisi, 8: 1307-9581.

Karakılçık, Y., \& Özcan, A. (2009). Türkiye'de Sulak Alanların Korunmasında Planlamanın Önemi ve Yerel Katılımın Gerekliliği. Çağdaş Yerel Yönetimler Dergisi, 18: 46-69.

Koralay, O.E., Candan, O., Akal, C., Dora, Ö.E, Chen, F., Satır, M., \& Oberhanslı, R. (2011). Menderes Masifindeki Pan- Afrikan ve Triyas Yaşlı Metagranitoyitlerin Jeolojisi ve Jeokronolijisi. Batı Anadolu Türkiye. MTA Dergisi, 142: 69-122.

Ma, Y., Zhu, Z., Zhong, L., Wang, B., Han,C., Wang, Z., Wang, Y., Lu, L., Amatya, P. M., Ma, W., \& Hu, Z. (2014). Combining MODIS, AVHRR and in situ data for evapotranspiration estimation over heterogeneous landscape of the Tibetan Plateau. Atmospheric Chemistry and Physics, 14: 1507-1515.

Müllenhoff, M., Handl, M., Knipping, M. \& Brückner H. (2004). The evolution of Lake Bafa (Western Turkey) Sedimentological. Microfaunal and Palynological Results. Coastline Reports, 1: 55-66.

Papastergiadou, E.S., Retalis, A., Apostolakis A., \& Georgiadis, Th. (2008). Environmental Monitoring of Spatio-temporal Changes Using Remote Sensing and GIS in a Mediterranean Wetland of Northern Greece. Water Resources Management, 22: 579594.

Soydan, E. (2013). Belgesel Filmlerin Sulak Alanların Korunmasında Rolü ve Önemi. 3. Ulusal Sulak Alanlar Kongresi, Samsun, s. 21-28.

Tunay, M., \& Ateşoğlu, A. (2004). Bartın İli Taşkın Sahalarındaki Değișimin Uzaktan Algılama Verileriyle İncelenmesi. Süleyman Demirel Üniversitesi Orman Fakültesi Dergisi, 2: 60-72.

Tunçay, H., Kelkit, A., Deniz B., Kara, B., \& Bolca, M. (2009). Peyzaj Strüktür İndeksleri ile Koruma Alanları ve Çevresindeki Peyzajın Geçirdiği Değişimin Tespiti ve Alan Kullanım Planlaması Önerilerinin Geliștirilmesi: Dilek Yarımadası-Menderes Deltası Milli Parkı ve Bafa Gölü Koruma Alanı Örneği. TÜBITAK, Çevre, Atmosfer, Yer ve Deniz Bilimleri Araștırma Grubu, Proje Sonuç Raporu, 172s. 